\section{PROCESS FOR PRODUCING DIAMOND-LIKE CARBIDE COATINGS ON HARD ALLOYS}

\section{ALEXANDER SHMATOV ${ }^{1}$, LUBOMIR SOOS², ZDENKO KRAJNY²}

${ }^{1}$ Belarusian National Technical University, Faculty of Mechanical Engineering, Minsk, Belarus

2Slovak Technical University, Faculty of Mechanical Engineering, Bratislava, Slovakia

DOI : 10.17973/MMSJ.2019_06_201812 e-mail: shmatovalexander@gmail.com

This article deals with the new surface hardening method for producing diamond-like multicomponent carbide coatings on tool hard alloys by high-temperature thermochemical heat treatment. The structure and properties of the obtained coatings are examined. For three-component systems for diffusion saturation of hard alloys, optimization of the powder mixtures was performed with respect to the wear resistance and microhardness of the multicomponent carbide coatings. The "composition-properties" diagrams were plotted using the obtained mathematical expressions. The optimal carbide coatings permit enhancing substantially the microhardness and service life of different hard alloy tools.

KEYWORDS:

thermochemical heat treatment, multicarbide coatings, optimization

\section{INTRODUCTION}

Deposition of hard carbide coatings onto the working surfaces is widely used for improving the wear resistance and durability of cutting and stamp tools [Hocking 1989], [Shmatov 1998]. A prospective direction of research in this area is the development of multicomponent carbide coatings [Shmatov 2018]. As is well known, dispersion-strengthened high-alloy steels and alloys containing alloyed carbides in their structure demonstrate higher properties than those having one-component carbides. However, the deposition of multicomponent carbide coatings on iron-carbon and hard alloys is scantily studied; most works deal with binary carbides while the ternary carbide coatings are almost not examined.

On the other hand, present-day methods of surface hardening typically cannot form carbide coatings alloyed simultaneously with several refractory metals [Hocking 1989]. Among the best methods of surface strengthening noteworthy is the plasma-activated CVD processes for depositing refractory compounds on the surface of articles. This method permits obtaining multilayer and multicomponent coatings, but each layer consists mainly of compounds (carbides, nitrides, oxides) formed by one and seldom by two alloying metals. But this process is energy and labor consuming, not very productive and requires the use of high-priced vacuum facilities and expensive consumables.

In connection with the above, the main purpose of this work is (i) a comparative analysis of structure and properties of one-, twoand three-component carbide coatings on tool hard alloys, (ii) optimization of the composition of multicomponent carbide coatings and (iii) the development of simple and inexpensive methods for deposition of carbide coatings onto steel stamps and hard-alloy cutting tools. The development of new wear resistant coating with microhardness of above $28,000 \mathrm{MPa}$, which exceeds the microhardness of silicon carbide, will improve the performance of hard alloy tools and permit processing materials with the hardness above HRC 60, and replacing, in certain operations, more expensive diamond tools.

\section{METHODS}

In this work, the processes of high-temperature thermochemical treatment (HTTCT) for producing wear-resistant carbide coatings on tool hard alloys are studied.

Multicomponent diffusion carbide coatings in the $\mathrm{Cr}-\mathrm{Ti}-\mathrm{V}, \mathrm{Cr}-\mathrm{Ti}-\mathrm{Mo}$, $\mathrm{Cr}-\mathrm{V}-\mathrm{Mo}, \mathrm{Cr}-\mathrm{V}-\mathrm{Nb}$, Ti-V-Mo systems were produced on hard alloys T15K6 (79\% WC, 15\% TiC and 6\% Co) and BK8 (92\% WC and 8\% Co). Specimens of hard alloys were placed into a container made of a heat-resistant steel, filled up with a specially synthesized powder media and sealed. The container was loaded into an electrical furnace heated to the processing temperature, $\mathrm{T}=1050{ }^{\circ} \mathrm{C}$ and held for 4-6 $\mathrm{h}$. The powder media were synthesized by reducing metal oxides $\mathrm{Me}_{\mathrm{x}} \mathrm{O}_{\mathrm{y}}$ with aluminum using the starting mixtures of the following compositions, wt.\%: $98 \%\left(50 \% \mathrm{Al}_{2} \mathrm{O}_{3}+35 \% \mathrm{Me}_{x} \mathrm{O}_{y}+15 \%\right.$ Al) $+2 \% \mathrm{NH}_{4} \mathrm{Cl}$, where the oxides $\mathrm{Me}_{\mathrm{x}} \mathrm{O}_{\mathrm{y}}=\mathrm{Cr}_{2} \mathrm{O}_{3}, \mathrm{TiO}_{2}, \mathrm{~V}_{2} \mathrm{O}_{5}, \mathrm{MoO}_{3}$, $\mathrm{Nb}_{2} \mathrm{O}_{5}$ were used as a source of the carbide-forming metals. After the synthesis, the obtained mixture was milled and, upon the addition of an energizer $\left(\mathrm{NH}_{4} \mathrm{Cl}\right)$ were used for performing HTTCT.

The structure and phase composition of the carbide coatings were examined using optical microscopy, X-ray diffraction (XRD) with depth profiling, electron probe microanalysis (EPMA) and microhardness testing. Wear tests of hard alloy cutting tools were performed by finish turning low-alloyed structural steel $40 \mathrm{X}(0.4 \% \mathrm{C}$, $1 \% \mathrm{Cr}$ ) (for coated T15K6 hard alloy) and gray cast irons (for coated BK8 hard alloy) on a lathe with the following regimes: the cutting speed of $100 \mathrm{~m} / \mathrm{min}$, the tool feed rate of $0.2 \mathrm{~mm}$ per revolution and cutting depth of $1 \mathrm{~mm}$. The relative wear resistance criterion for the carbide coatings was calculated as $K_{w}=t_{2} / t_{1}$, where $t_{1}$ is the service time of an uncoated hard alloy insert till a wear cratering with the depth of $0.8 \mathrm{~mm}$ was formed on the back edge of the cutter, $t_{2}$ is the time before the formation of a $0.5 \mathrm{~mm}$ deep wear cratering on a coated hard alloy insert.

To optimize the composition of the powder media for HTTCT process in regard to the properties (wear resistance and microhardness) and reduce the number of experiments, the socalled simplex method of the design of experiments [Novik 1971] was employed for 19 experiments in each of five systems: Cr-Ti-V, $\mathrm{Cr}-\mathrm{Ti}-\mathrm{Mn}, \mathrm{Cr}-\mathrm{Ti}-\mathrm{Mo}$, Cr-V-Mo, Cr-V-Nb, Ti-V-Mo for the studied grades of hard alloys. The obtained mathematical expressions were used to plot the "composition-properties" diagrams.

\section{RESEARCH RESULTS}

The HTTCT of hard alloy inserts in the synthesized powder media results in the formation of continuous multicomponent carbide coatings of uniform thickness, 4-9 $\mu \mathrm{m}$, based on complex carbides, e.g., (TiV)C, $\left(\mathrm{Ti}_{x} \mathrm{Cr}_{1-\mathrm{x}}\right) \mathrm{C},\left(\mathrm{Ti}_{\mathrm{x}} \mathrm{Mo}_{1-\mathrm{x}}\right) \mathrm{C}$. The formation of multicomponent multiphase carbide coatings has complex nature and comes out from diffusion interaction of in-diffusing carbideforming metal species with carbon contained in the tungsten and titanium carbides inside the hard alloy. The diffusion saturation of the surface of a hard alloy with carbide-forming metals from the 
powder medium is accompanied by redistribution of the elements ( $\mathrm{W}, \mathrm{Ti}$ and $\mathrm{Co})$ in the underlying material because of the cross-term effects Because of these reasons, the HTTCT brings about the formation of non-equilibrium phase composition of the obtained carbide coatings.

The comparative data on the maximal wear resistance and maximal microhardness of one-, two- and three-component carbide coatings in systems $\mathrm{Cr}-\mathrm{Ti}-\mathrm{V}, \mathrm{Cr}-\mathrm{Ti}-\mathrm{Mo}, \mathrm{Cr}-\mathrm{V}-\mathrm{Mo}, \mathrm{Cr}-\mathrm{V}-\mathrm{Nb}$ and Ti-V-Mo on hard alloy BK8 are presented in Fig. 1 and Fig. 2. Similar results for hard alloy T15K6 is shown in Fig. 3 and Fig. 4. It should be outlined that the maximal level of wear resistance and microhardness of these two-component carbide coatings was chosen among three variants of coatings, and for three-component carbide coatings the choice was made among seven variants of coatings. A linear correlation has been found between the wear resistance and the microhardness of carbide coatings on the T15K6 and BK8 hard alloys in five systems: the coefficient of pair correlation is 0.74-0.99 (Tab. 1).

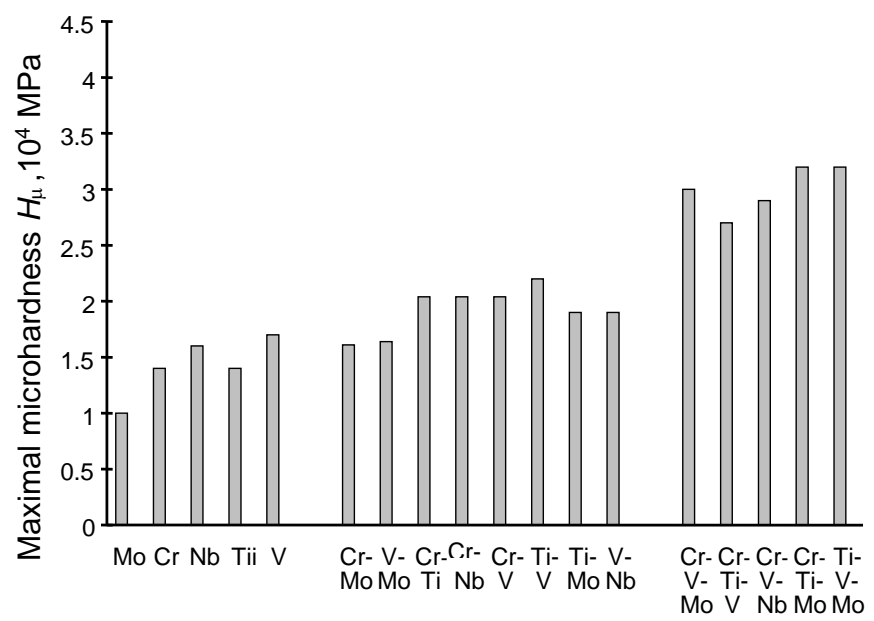

Figure 1. Diagram of maximal microhardness $H_{\mu}$ of carbide coatings on hard alloy BK8

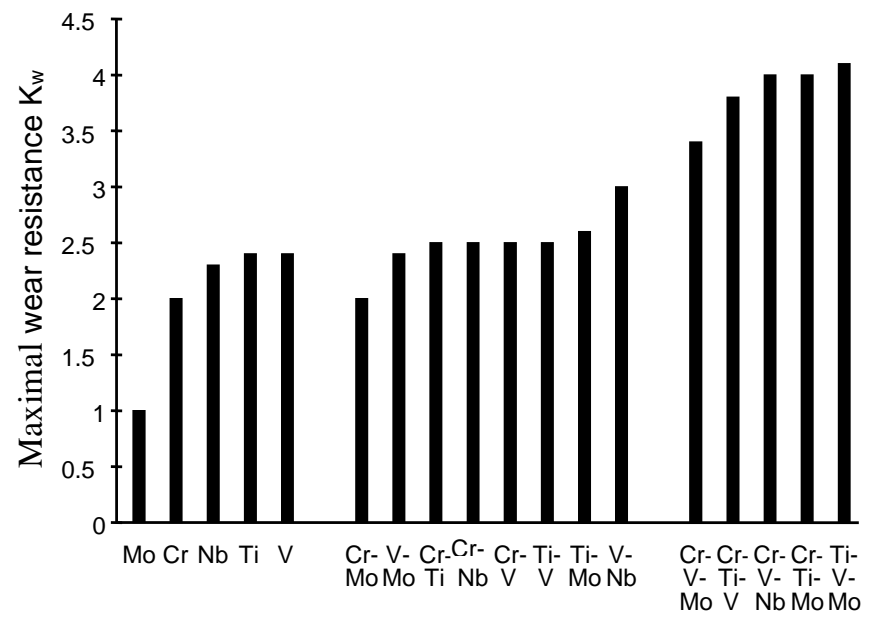

Figure 2. Diagram of maximal wear resistance $K_{\mathrm{w}}$ of carbide coatings on hard alloy BK8

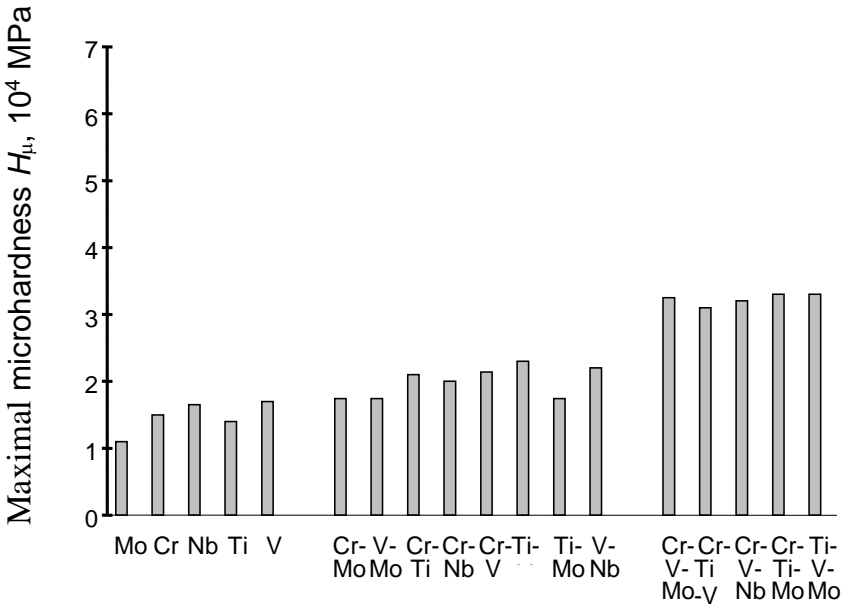

Figure 3. Diagram of maximal microhardness $H_{\mu}$ of carbide coatings on hard alloy T15K6

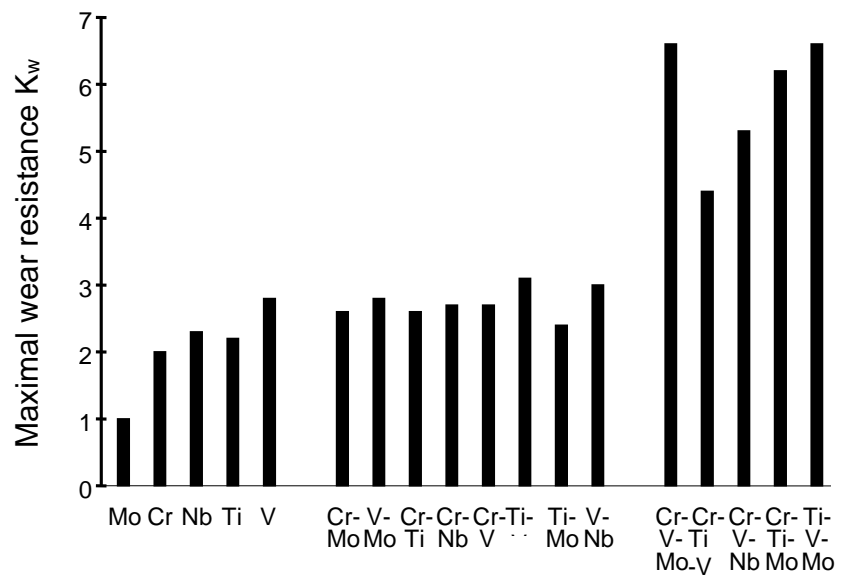

Figure 4. Diagram of maximal wear resistance $K_{\mathrm{w}}$ of carbide coatings on hard alloy T15K6

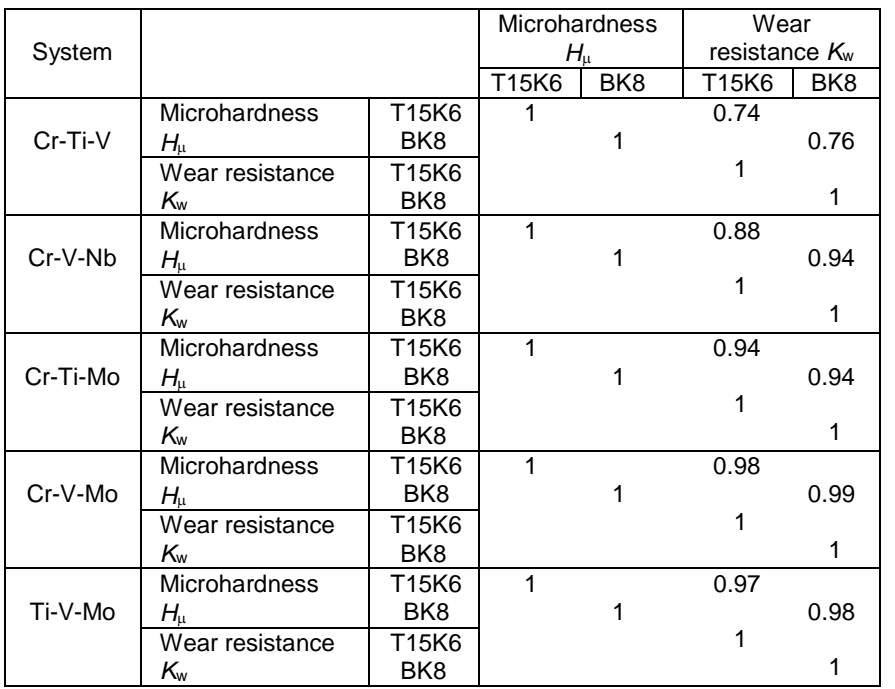

Table 1. Pair correlation coefficients between wear resistance $K_{w}$ and microhardness $H_{\mu}$ of carbide coatings on hard alloys T15K6 and BK8

The relative wear resistance criterion, thickness of the coatings and microhardness are presented in Tab. 2. 


\begin{tabular}{|c|c|c|c|c|c|c|}
\hline Type of & \multicolumn{2}{|c|}{$K_{w}$} & \multicolumn{2}{|c|}{$H_{\mu}, 10^{3} \mathrm{MPa}$} & \multicolumn{2}{|c|}{$\delta, \mu \mathrm{m}$} \\
\hline $\begin{array}{c}\text { One- } \\
\text { component }\end{array}$ & $\begin{array}{c}\text { T15K6 } \\
1-2.8\end{array}$ & $\begin{array}{l}\text { BK8 } \\
1-2.4\end{array}$ & $\begin{array}{l}\text { T15K6 } \\
11.0-17.0\end{array}$ & $\begin{array}{l}\text { BK8 } \\
10.0-17.0\end{array}$ & $\begin{array}{c}\text { T15K6 } \\
7-10\end{array}$ & $\begin{array}{l}\text { BK8 } \\
7-12\end{array}$ \\
\hline $\begin{array}{l}\text { Two- } \\
\text { component }\end{array}$ & $\begin{array}{l}2.4- \\
3.1\end{array}$ & $2-3$ & $17.4-23.0$ & $16.1-22.0$ & $4-8$ & $6-9$ \\
\hline $\begin{array}{l}\text { Three- } \\
\text { component }\end{array}$ & $\begin{array}{r}4.4- \\
6.6\end{array}$ & $\begin{array}{c}3.4- \\
4.1\end{array}$ & $31.0-33.0$ & $27.0-32.0$ & 4 & $5-7$ \\
\hline
\end{tabular}

Table 2. Relative wear resistance criterion $K_{w}$, thickness $\delta$, and microhardness $H_{\mu}$ of carbide coatings on T15K6 and BK8 hard alloys

From Fig. 1, Fig. 2, Fig. 3, Fig. 4 and Tab. 2 it is obvious that the tested properties (microhardness and wear resistance) of threecomponent carbide coatings exceed those of one- and twocomponent coatings. This is due to the following factors: (i) the predominance of carbides having high hardness such as TiC, VC and $\mathrm{NbC}$ in the coating, (ii) the formation of alloy carbides containing up to $3-20 \%$ of alloying elements, and (iii) the texture of carbide grains (up to $30 \%$ of the theoretical value). The improvement of wear resistance strongly depends on the thickness of the coating, the optimal thickness being 4-7 $\mu \mathrm{m}$. The deposition of a thicker coating onto a high alloy surface is accompanied by the formation of an interlayer of a brittle intermetallic $\eta$-phase. It has been revealed that for cutting tools, three-component carbide coatings in the $\mathrm{Cr}$-Ti-Mo and Ti-V-Mo systems with homogeneous structure, which contain up to $81 \%$ complex carbides $\left[\mathrm{Ti}_{96}(\mathrm{Cr}, \mathrm{Mo})_{4}\right] \mathrm{C}$ and $\left[(\mathrm{TiV})_{96} \mathrm{Mo}_{4}\right] \mathrm{C}$, possess maximal hardness and wear resistance at turning on a lathe.

For five three-component systems, viz. Cr-Ti-V, Cr-Ti-Mo, Cr-V-Mo, $\mathrm{Cr}-\mathrm{V}-\mathrm{Nb}$ and $\mathrm{Ti}-\mathrm{V}-\mathrm{Mo}$, optimization of the starting powder mixtures was performed with respect to the wear resistance and microhardness of the carbide coatings produced on T15K6 and BK8 hard alloys. In this work, we present, as an example, optimization for only one system out of five of three-component systems, viz. $\mathrm{Cr}$-TiMo. It was performed in the following way. In accordance to the simplex method of the design experiment, the design matrix (Tab. 3) for the Cr-Ti-Mo system was composed using the obtained results of the properties of carbide coatings, where wear resistance and microhardness was used as the optimization parameter $(\mathrm{y})$ and the mass fraction of metal oxides $\mathrm{Cr}_{2} \mathrm{O}_{3}\left(\mathrm{x}_{1}\right), \mathrm{TiO}_{2}\left(\mathrm{x}_{2}\right), \mathrm{MoO}_{3}\left(\mathrm{x}_{3}\right)$ in the powder mixture were used as independent variable data.

\begin{tabular}{|c|c|c|c|c|c|c|c|}
\hline \multicolumn{3}{|c|}{$\begin{array}{l}\text { The rate of metal oxides in } \\
\text { powder mixture } \\
\text { (weight fraction) }\end{array}$} & \multirow[t]{2}{*}{$\begin{array}{c}\text { Parameter } \\
y\end{array}$} & \multicolumn{2}{|c|}{$\begin{array}{c}\text { Microhardness } \\
H_{\mu}, \mathrm{MPa}\end{array}$} & \multicolumn{2}{|c|}{$\begin{array}{l}\text { Relative wear } \\
\text { resistance } \\
\text { criterion } K_{w}\end{array}$} \\
\hline $\begin{array}{c}\mathrm{Cr}_{2} \mathrm{O}_{3} \\
\left(\mathrm{x}_{1}\right)\end{array}$ & $\begin{array}{l}\mathrm{TiO}_{2} \\
\left(\mathrm{x}_{2}\right)\end{array}$ & $\begin{array}{c}\mathrm{MoO}_{3} \\
\left(\mathrm{x}_{3}\right)\end{array}$ & & T15K6 & BK8 & T15K6 & BK8 \\
\hline 1 & 0 & 0 & $y_{1}$ & 15000 & 14000 & 2.0 & 2.0 \\
\hline $3 / 4$ & $1 / 4$ & 0 & $\mathrm{y}_{1112}$ & 18100 & 16500 & 2.2 & 1.5 \\
\hline $1 / 2$ & $1 / 2$ & 0 & $\mathrm{y}_{12}$ & 21400 & 20400 & 2.6 & 2.5 \\
\hline $1 / 4$ & $3 / 4$ & 0 & $\mathrm{y}_{1222}$ & 19000 & 17100 & 2.0 & 2.4 \\
\hline 0 & 1 & 0 & $\mathrm{y}_{2}$ & 14000 & 14000 & 2.2 & 2.4 \\
\hline 0 & $3 / 4$ & $1 / 4$ & $\mathrm{y}_{2223}$ & 17400 & 19000 & 2.4 & 2.6 \\
\hline 0 & $1 / 2$ & $1 / 2$ & $\mathrm{y}_{23}$ & 18300 & 21700 & 1.5 & 2.0 \\
\hline 0 & $1 / 4$ & $3 / 4$ & $\mathrm{y}_{2333}$ & 13200 & 14000 & 1.2 & 1.3 \\
\hline 0 & 0 & 1 & $\mathrm{y}_{3}$ & 11000 & 10000 & 1.0 & 1.0 \\
\hline $1 / 4$ & 0 & $3 / 4$ & $\mathrm{y}_{1333}$ & 15000 & 13700 & 2.0 & 1.2 \\
\hline $1 / 2$ & 0 & $1 / 2$ & $\mathrm{y}_{13}$ & 17400 & 16100 & 2.6 & 2.0 \\
\hline $3 / 4$ & 0 & $1 / 4$ & $\mathrm{y}_{1113}$ & 19200 & 18000 & 2.4 & 1.7 \\
\hline $1 / 2$ & $1 / 4$ & $1 / 4$ & $\mathrm{y}_{1123}$ & 28000 & 24000 & 3.0 & 3.2 \\
\hline $1 / 4$ & $1 / 2$ & $1 / 4$ & $\mathrm{y}_{1223}$ & 32500 & 31700 & 6.2 & 3.8 \\
\hline $1 / 4$ & $1 / 4$ & $1 / 2$ & $\mathrm{y}_{1233}$ & 33000 & 31900 & 6.2 & 4.0 \\
\hline $1 / 3$ & $1 / 3$ & $1 / 3$ & $\mathrm{y}_{123}$ & 33000 & 31000 & 5.1 & 4.0 \\
\hline $1 / 8$ & $3 / 4$ & $1 / 8$ & - & 17000 & 16000 & 1.5 & 1.7 \\
\hline $1 / 8$ & $1 / 8$ & $3 / 4$ & - & 19000 & 19000 & 3.1 & 2.8 \\
\hline $3 / 4$ & $1 / 8$ & $1 / 8$ & - & 14000 & 13000 & 3.0 & 1.0 \\
\hline
\end{tabular}

Table 3. Design matrix and properties (relative wear resistance criterion $K_{\mathrm{w}}$, and microhardness $H_{\mu}$ ) of carbide coatings on hard alloys T15K6 and BK8 for the Cr-Ti-Mo system
At that, the total amount of metal oxides $\mathrm{Me}_{x} \mathrm{O}_{y}$ in the $\mathrm{Cr}$-Ti-Mo powder mixture containing $98 \%\left(50 \% \mathrm{Al}_{2} \mathrm{O}_{3}+35 \% \mathrm{Me}_{\mathrm{x}} \mathrm{O}_{\mathrm{y}}+15 \% \mathrm{Al}\right)+$ $2 \% \mathrm{NH}_{4} \mathrm{Cl}$ is constant, i.e. the total amount $\mathrm{Cr}_{2} \mathrm{O}_{3}+\mathrm{TiO}_{2}+\mathrm{MoO}_{3}$ equals $100 \%$ (or 1 in weight fractions).

The second, third and fourth order mathematical models describing the effect of the powder mixture composition on properties of the $\mathrm{Cr}$-Ti-Mo carbide coatings, were used whereas the second and third order mathematical models appeared inadequate.

The fourth order mathematical models are the following: for wear resistance of carbide coatings on T15K6 hard alloys: $y=2.0 x_{1}+2.2 x_{2}+x_{3}+2.0 x_{1} x_{2}+4.4 x_{1} x_{3}-0.4 x_{2} x_{3}-204.8 x_{1} x_{2}\left(x_{1}-x_{2}\right)+$ $+226.3 x_{1} x_{3}\left(x_{1}-x_{3}\right)+244,3 x_{2} x_{3}\left(x_{2}-x_{3}\right)+1.6 x_{1} x_{2}\left(x_{1}-x_{2}\right)^{2-}$ $-0.5 x_{1} x_{3}\left(x_{1}-x_{3}\right)^{2}+3.2 x_{2} x_{3}\left(x_{2}-x_{3}\right)^{2}-8.0 x_{1}^{2} x_{2} x_{3}-2.7 x_{1} x_{2}^{2} x_{3}++5.9 x_{1} x_{2} x_{3}^{2}$;

for wear resistance of carbide coatings on BK8 hard alloys $y=2.0 x_{1}+2.4 x_{2}+x_{3}+1.2 x_{1} x_{2}+2.0 x_{1} x_{3}+1.2 x_{2} x_{3}-1.6 x_{1} x_{2}\left(x_{1}-x_{2}\right)+$ $+19.7 x_{1} x_{3}\left(x_{1}-x_{3}\right)+123,2 x_{2} x_{3}\left(x_{2}-x_{3}\right)+3.7 x_{1} x_{2}\left(x_{1}-x_{2}\right)^{2}+$ $+3.2 x_{2} x_{3}\left(x_{2}-x_{3}\right)^{2}-10.1 x_{1}^{2} x_{2} x_{3}-9.1 x_{1} x_{2}^{2} x_{3}+0.5 x_{1} x_{2} x_{3}^{2}$;

for microhardness of carbide coatings on T15K6 hard alloys $y=1500 x_{1}+1700 x_{2}+900 x_{3}+1800 x_{1} x_{2}+1800 x_{1} x_{3}+3400 x_{2} x_{3}-$ $-4200 x_{1} x_{2}\left(x_{1}-x_{2}\right)+5000 x_{1} x_{3}\left(x_{1}-x_{3}\right)+76.7 x_{2} x_{3}\left(x_{2}-x_{3}\right)++270 x_{1} x_{2}\left(x_{1}-\right.$ $\left.x_{2}\right)^{2}+1200 x_{1} x_{3}\left(x_{1}-x_{3}\right)^{2}+5.9 x_{2} x_{3}\left(x_{2}-x_{3}\right)^{2}-2900 x_{1}^{2} x_{2} x_{3}+1700 x_{1} x_{2}^{2} x_{3}-$ $67700 x_{1} x_{2} x_{3}^{2}$

for microhardness of carbide coatings on BK8 hard alloys $y=1400 x_{1}+1700 x_{2}+1000 x_{3}+1900 x_{1} x_{2}+1600 x_{1} x_{3}+3300 x_{2} x_{3}$ $-4100 x_{1} x_{2}\left(x_{1}-x_{2}\right)+4800 x_{1} x_{3}\left(x_{1}-x_{3}\right)+790 x_{2} x_{3}\left(x_{2}-x_{3}\right)+500 x_{1} x_{2}\left(x_{1}-\right.$ $\left.x_{2}\right)^{2}+12600 x_{1} x_{3}\left(x_{1}-x_{3}\right)^{2}+800 x_{2} x_{3}\left(x_{2}-x_{3}\right)^{2}-5100 x_{1}^{2} x_{2} x_{3}++1700 x_{1} x_{2}^{2} x_{3}-$ $6700 x_{1} x_{2} x_{3}^{2}$.

Numerical calculations have shown that all the above listed models are adequate.

The obtained mathematical expressions were used to plot the "composition-properties" diagrams (Fig. 5, Fig. 6, Fig. 7, Fig. 8). The diagrams show that for the Cr-Ti-Mo system, the optimal regions for all the tested properties lie approximately within the following range: $10-40 \% \mathrm{Cr}_{2} \mathrm{O}_{3}, 30-65 \% \mathrm{TiO}_{2}, 15-50 \% \mathrm{MoO}_{3}$. Here, the wear resistance of carbide coatings on hard alloys with standard chemical composition increases by the factor of 5.9-6.4 for T15K 6 and 4.2-4.7 for BK8, microhardness imroves by the factor of 30,500-35,000 MPa for T15K6 and 28,500-33,000 MPa for BK8 as compared with uncoated materials.

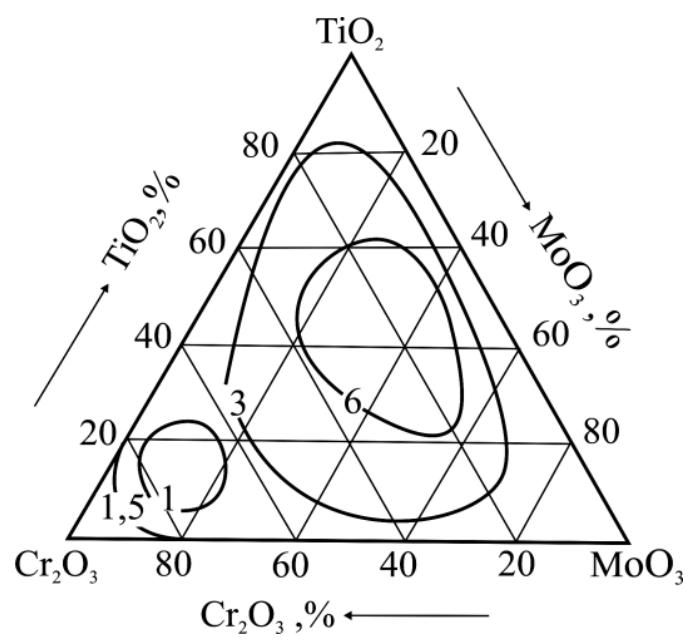

Figure 5. Effect of the powder composition on wear resistance $K_{\mathrm{w}}$ of $\mathrm{Cr}$-Ti-Mo carbide coatings on hard alloy T15K6 


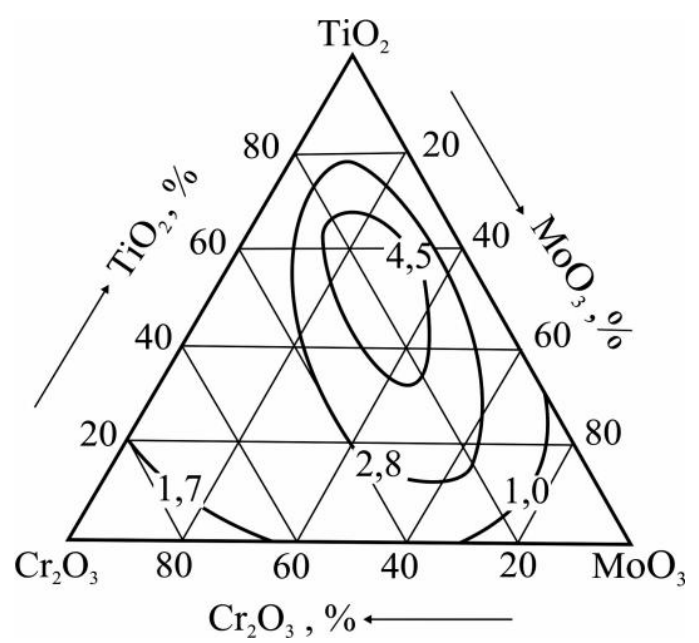

Figure 6. Effect of the powder composition on wear resistance $K_{\mathrm{w}}$ of $\mathrm{Cr}$-Ti-Mo carbide coatings on hard alloy BK8

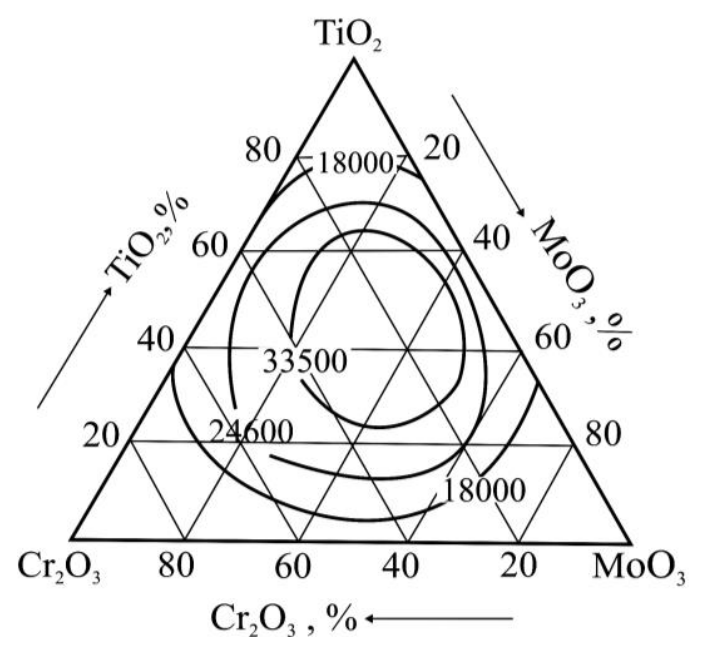

Figure 7. Effect of the powder composition on microhardness $\mathrm{H}_{\mu}$ of $\mathrm{Cr}$-Ti-Mo carbide coatings on hard alloy T15K6

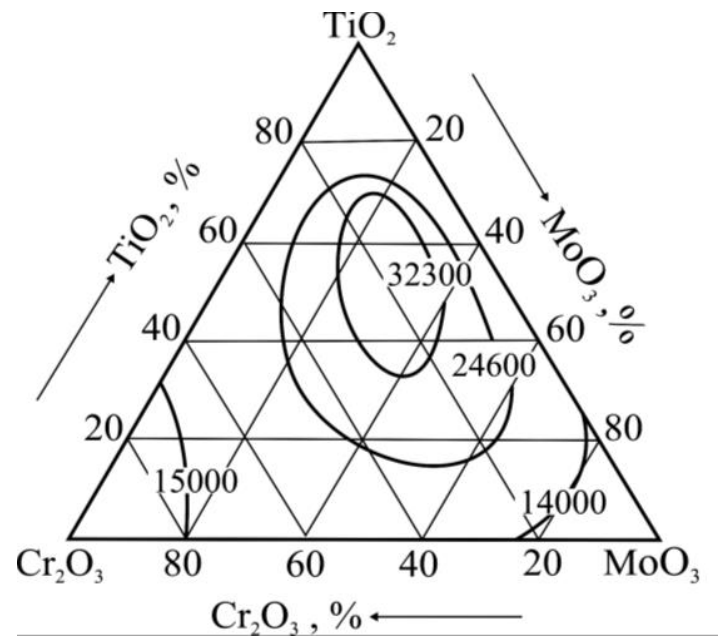

Figure 8. Effect of the powder composition on microhardness $\mathrm{H}_{\mu}$ of $\mathrm{Cr}$-Ti-Mo carbide coatings on hard alloy BK8.
Optimal compositions of powder mixtures for the remaining four systems were obtained in a similar way. The optimal composition regions for two grades of hard alloys appear to be the following:

Cr-Ti-V: $\quad 10-45 \% \mathrm{Cr}_{2} \mathrm{O}_{3}, 40-60 \% \mathrm{TiO}_{2}, 10-40 \% \mathrm{~V}_{2} \mathrm{O}_{5}$,

Cr-Ti- Mo: $\quad 20-30 \% \mathrm{Cr}_{2} \mathrm{O}_{3}, 40-60 \% \mathrm{TiO}_{2}, 20-30 \% \mathrm{MoO}_{3}$,

Ti-V-Mo: $\quad 20-30 \% \mathrm{~V}_{2} \mathrm{O}_{5}, 40-60 \% \mathrm{TiO}_{2}, 20-30 \% \mathrm{MoO}_{3}$,

Cr-V-Nb: $\quad 10-40 \% \mathrm{Cr}_{2} \mathrm{O}_{3}, 25-55 \% \mathrm{~V}_{2} \mathrm{O}_{5}, 20-45 \% \mathrm{Nb}_{2} \mathrm{O}_{5}$,

Cr-V-Mo: $\quad 10-45 \% \mathrm{Cr}_{2} \mathrm{O}_{3}, 20-60 \% \mathrm{~V}_{2} \mathrm{O}_{5}, 15-50 \% \mathrm{MoO}_{3}$.

The results of laboratory and industrial testing have demonstrated that these optimal compositions of the powder media permit increasing the service life of disposable (not subjected to resharpening) hard alloy tool inserts at finish and rough turning or milling by the factor of 2-6 as compared with the uncoated inserts. Hard alloy end mills of a different diameter $(4-8 \mathrm{~mm})$ with a Ti-V-Mo carbide coating were tested in industrial conditions by milling a hardened stamp steel 6X6B3MФC $(0.6 \% \mathrm{C}, 6 \% \mathrm{Cr}, 0.9 \%, 3 \% \mathrm{~W}, 0.8 \%$ $\mathrm{V})$ with hardness HRC 62. Their wear resistance was found to increase by the factor of 6-20 in comparison with uncoated tools.

It should be noted that the use of metal oxides in the starting powder mixture instead of pure metals yielded a substantial decrease in the cost of the mixtures, by the factor of 2-10 thus improving the cost efficiency and versatility of the developed HTTCT process.

The proposed surface hardening method has the following advantages over the known technologies of coatings deposition:

- the process is simple and cost-efficient due to the use of standard equipment, cheap metal oxide media and relatively low temperature;

- thorough cleaning of the surface is not required.

\section{CONCLUSIONS}

The developed multicomponent carbide coatings permit increasing significantly the wear resistance of hard alloy cutting tools in comparison with one- and two-component coatings. Simple, cost efficient and high-performance method for depositing wear resistant carbide coatings is developed which may replace the existing technologies of surface strengthening of hard alloys cutting tools.

\section{REFERENCES}

[Hocking 1989] Hocking, M. G., Vasantasree, V., Sidky, P. S. Metallic and Ceramic Coatings: Production, Properties and Applications London, 518 p. 1989.

[Shmatov 1998] Shmatov, A. A.: Advanced Coatings \& Surface Technology, Vol. 11, No. 1, pp. 5-6. 1998

[Shmatov 2018] Shmatov, A., Soos, L., Krajny, Z. Forming of diffusion multi-carbide coatings on tool alloys (a monograph) - Bratislava, 137 p. 2018.

[Novik 1971] Novik, F.S., Mathematical Methods of Design of Experimens in Materials Science - Moscow, Chap. 4, 148 p. 1971.

\section{CONTACTS:}

Dr. Alexander Shmatov, docent, Ph.D.

Belarusian National Technical University

Faculty of Mechanical Engineering

Nezavisimosti ave., 65, 220013 Minsk, Belarus

Tel.: +375 293777 357, +375 447779213

e-mail: shmatovalexander@gmail.com 